Przegląd Badań Edukacyjnych

ISSN 1895-4308

nr 18 (1/2014), s. 91-102

METAANALIZY

BADAŃ

EDUKACYJNYCH

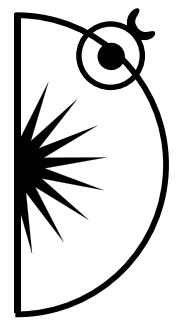

Marzenna Zaorska

\title{
Organizacja oraz realizacja badań naukowych osób dorosłych z niepełnosprawnością sprzężoną (na przykładzie osób głuchoniewidomych) za granicą - możliwości i ograniczenia
}

DOI: http://dx.doi.org/10.12775/PBE.2014.007

\section{Wprowadzenie}

Badania naukowe realizowane w pedagogice specjalnej posiadają swoją szczególność oraz specyfikę. Owa szczególność oraz specyfika wynikają z trzech zasadniczych kwestii: pierwszą jest podmiot zainteresowań - osoby (dzieci, młodzież, dorośli) z różnym typem niepełnosprawności; drugą ich specyficzne i szczególne potrzeby rozwojowe, funkcjonalne, życiowe korespondujące z indywidualnymi możliwościami oraz typem niepełnosprawności; trzecią - historycznie i socjo-kulturowo uwarunkowane mentalne i ogólnospołeczne nastawienia oraz percepcje osób z niepełnosprawnościami, niejednokrotnie na tyle zakorzenione w postawach i działaniach społecznych, że dokonanie jakichkolwiek przewartościowań, modyfikacji czy transformacji wymaga nie tylko reform systemowych w funkcjonowaniu różnych struktur społecznych, ale także legislacyjnie unormowanych kroków prawnych.

W obszarze podmiotu naukowych dociekań oraz naukowych eksploracji współczesnej pedagogiki specjalnej pewną wyjątkowością i szczególnością charakteryzują się osoby, które przez dziesięciolecia (a nawet stulecia), z róż- 
nych przyczyn, znajdowały się w zakresach marginalizowanych nie tylko przez społeczeństwo, ale również przez samą pedagogikę specjalną. Do tej grupy należą niewątpliwie osoby z niepełnosprawnością sprzężoną, złożoną, wielozakresową, wieloraką, wśród nich między innymi osoby głuchoniewidome. Aczkolwiek w perspektywie osób głuchoniewidomych, to w ogólnej populacji ludzi z niepełnosprawnością sprzężoną, osoby takie znajdowały się na stosunkowo uprzywilejowanej pozycji, jeśli w ogóle o jakimkolwiek uprzywilejowaniu można w ich przypadku mówić.

Badania naukowe obejmujące ludzi ze sprzężoną niepełnosprawnością, w tym głuchoniewidomych, mają iście skonkretyzowany, zindywidualizowany oraz definiowany istotą niepełnosprawności charakter. Wymagają zastosowania interpretacyjnego podejścia do realizowanych strategii badawczych oraz uzyskanych wyników, które może być w określonym względzie obciążone subiektywizacją poznawanego, tak w korelacie relacyjnym, pozyskiwanych danych, jak i ich naukowego ujęcia. Owe ograniczenia nie powinny jednak stanowić argumentu na rezygnację $\mathrm{z}$ realizacji badania analizowanych populacji osób z niepełnosprawnością. Powinny raczej być stymulatorem do poszukiwania i zrozumienia procesów rozwojowych i funkcjonalnych oraz wypracowania maksymalnie dostosowanych do ich indywidualnych potrzeb działań systemowych, jak również zindywidualizowanych pod adresem konkretnej osoby ludzkiej.

Niezwykle trudnym wyzwaniem dla badacza zdaje się, i w rzeczy samej jest, stan niepełnosprawności sprzężonej obecny od urodzenia lub wczesnego dzieciństwa. Na przykład w sytuacji uszkodzenia dwóch najważniejszych zmysłów - słuchu i wzroku powstaje gros pytań o to, na ile na rozwój takiej osoby wpływ działań wychowawczo-socjalizacyjnych oraz rehabilitacyjnych uruchamia własny potencjał rozwojowy człowieka, i pytań o to, na ile ów rozwój jest odzwierciedleniem, przejętą kalką postaw, zachowań, poglądów preferencji osób realizujących zadania wychowawczo-rehabilitacyjne. Mówiąc inaczej, na ile, np. człowiek głuchoniewidomy został „wyrzeźbiony” przez „socjalizatorów”, na ile przez siebie samego, a na ile zarówno przez „socjalizatorów”, jak i siebie samego.

Organizacja oraz realizacja badań naukowych obejmujących osoby z niepełnosprawnością sprzężoną wymagają więc od badacza uwzględnienia nie tylko specyfiki podmiotu, który obejmują, ale także wielu innych, adekwatnych i korespondujących ze specyfiką podmiotu determinantów, jak również możliwych wpływów środowiska/środowisk życia, współdecydujących o przebiegu indywidualnej ścieżki rozwoju i rzutujących na aktualnie uzyskany po- 
ziom społecznego oraz osobistego funkcjonowania. Przed badaczem pojawia się wielość problemów, a są one tym bardziej potęgowane, jeśli dotyczą osób z niepełnosprawnością sprzężoną w wymiarze zagranicznym. Stąd poniżej zostaną wskazane wybrane uwarunkowania prowadzenia badań naukowych obejmujących podmioty zagraniczne na przykładzie doświadczeń własnych, wynikających z realizacji projektu badawczego Ministerstwa Nauki i Szkolnictwa Wyższego (numer projektu badawczego: N N106 0950 33) na temat: „Edukacja i rehabilitacja osób głuchoniewidomych w Polsce i Rosji (aspekt historyczny oraz stan obecny)"

\section{Założenia organizacyjne zrealizowanych badań własnych osób dorosłych głuchoniewidomych*}

Badaniom w obszarze głuchoślepoty przyświecała idea wskazania osiągnięć życiowych, zasobów, możliwości osób głuchoniewidomych, a nie ograniczeń czy ewentualne niemożności. Podjęcie badań było motywowane potrzebą interdyscyplinarnego i systemowego podejścia do poznania determinantów współdecydujących o uzyskaniu przez osobę głuchoniewidoma, uznawanego za wysoki, poziomu funkcjonowania. Ponadto celem badań było opisanie genezy i organizacji systemu edukacji i rehabilitacji osób głuchoniewidomych w Polsce oraz w Rosji. Chodziło o porównanie, dokonanie przeglądu poglądów, koncepcji, działań, dominujących tendencji mentalnych w nastawieniach do osób głuchoniewidomych i ich możliwości w ujęciu historycznym oraz współczesnym. Ważne też było wskazanie rozwiązań systemowych w istniejących propozycjach programowych działań na rzecz wspomagania głuchoniewidomych w Polsce i Rosji. Dodatkowo, badania miały służyć poznaniu statystyk osób objętych zorganizowanym kształceniem oraz efektywności tegoż kształcenia na podstawie konkretnych biografii ludzi, którzy osiągnęli imponujące sukcesy życiowe. Celem było również poznanie procesu dochodzenia osób głuchoniewidomych do autonomicznego funkcjonowania i procesu dochodzenia specjalistów do zainteresowania się problematyką głuchoślepoty.

Wymiernym efektem badań było opracowanie rekomendacji adresowanych do praktyki pedagogicznej w kwestii możliwości modyfikacji już zbudowanych strategii programowych i metodycznych w obszarze edukacji i rehabilitacji głuchoniewidomych w Polsce. Wybór Rosji wynikał z dwóch podstawowych

* M. Zaorska, Edukacja i rehabilitacja osób głuchoniewidomych w Polsce i Rosji (rozwój $i$ stan obecny), Wydawnictwo UMK, Toruń 2010, s. 9-21. 
faktów: 1) doświadczeń w sferze zorganizowanego, instytucjonalnego kształcenia osób głuchoniewidomych, które sięgają roku 1894 (w Polsce datowane są na rok 1953); 2) okresu po drugiej wojnie światowej w Polsce, który łączył nasz kraj, a także panujące w nim rozwiązania w obszarze edukacji z systemem panującym w ówczesnym Związku Radzieckim. W badaniach po raz pierwszy podjęto próbę analizy i oceny porównawczej rozwiązań systemowych w sferze kształcenia głuchoniewidomych w Polsce i Rosji w aspekcie historii i współczesności. Znaczącym novum była charakterystyka osiagnięć wybranych osób w dziedzinie surdotyflopedagogiki, tak z grona samych głuchoniewidomych, jak i specjalistów pracujących z ludźmi głuchoniewidomymi.

Realizacja badań odbywała się w ramach specjalnie przygotowanego i odpowiednio zorganizowanego projektu badawczego. Wymagała wykorzystania wybranych metod badań pedagogicznych, przede wszystkim metod preferowanych w strategiach jakościowych (opartych na paradygmacie jakościowym), konkretnie metody biograficznej oraz jakościowej analizy tekstów. Skorzystano też $\mathrm{z}$ metod dominujących $\mathrm{w}$ badaniach historycznych, zasadniczo $\mathrm{z}$ analizy materiałów źródłowych: literatury naukowej, popularnonaukowej, doniesień prasowych, notatek osobistych badanych. Pomocne przy tym były następujace techniki badawcze: wywiad biograficzny, rozmowa, analiza dokumentacji, obserwacja uczestnicząca, analiza dokumentów historycznych, analiza informacji statystycznych będących w posiadaniu ministerstw odpowiedzialnych za oświatę w Polsce i Rosji.

Badania jakościowe zdaniem K. Rubachy „pozwalają formułować prawidłowości odnoszone do jednostkowych miejsc i indywidualnych doświadczeń badanych, pozwalają budować teorie ugruntowane, czyli zbiory twierdzeń wyjaśniających jednostkowe doświadczenie i zjawiska występujące w badanym terenie. Teorie te są ugruntowane $\mathrm{w}$ danych, co oznacza, że nie można ich wykorzystywać do wyjaśnień wykraczających poza badane miejsce i czas, pozwalają budować typologie obiektów należących do danej klasy, powstające na podstawie dogłębnego opisu konkretnych badanych osób" ${ }^{1 "}$.

Sedno metody biograficznej z kolei w ujęciu T. Bauman, „opiera się na założeniu, iż nie istnieje - w sensie obiektywnym - żaden przedmiotowy wymiar rzeczywistości społecznej. Wiedza o społeczeństwie jest wiedzą „czyją̧́" a są takie obszary rzeczywistości społecznej, które możemy poznać jedynie przez ukazanie ich osobistego wymiaru. Można by założyć, że wie-

${ }^{1}$ K. Rubacha, Metodologia badań nad edukacja, Wydawnictwo Akademickie i Profesjonalne, Warszawa 2008, s. 20-21. 
dza o społeczeństwie, o człowieku zbudowana jest niejako z dwóch warstw: jedną jest warstwa faktograficzna, drugą zaś stanowi indywidualny i symboliczny wymiar zjawisk społecznych. (...) obydwie te warstwy przenikają się wzajemnie i dopiero poznanie ich obydwu daje pełniejszy obraz człowieka i społeczeństwa ${ }^{2 "}$.

Termin ,metoda biograficzna jest stosowany w odniesieniu do luźno powiązanego zestawu strategii badawczych odwołujących się do różnych założeń teoretycznych i metod ${ }^{3}$."Jest też metodą analizy życia ludzkiego w relacji do określonego wycinka rzeczywistości społecznej. Techniką, możliwą do wykorzystania w metodzie biograficznej, jest ,wywiad biograficzny - łączy kwestionariusz - dialog z formą monologu swobodnego - opowieści o życiu badanego oraz kwestionariusz interpretacyjny - dialog uściślający rozumienie i oceny respondent ${ }^{4}$." Metoda biograficzna preferuje badanie ludzkich działań w kontekście subiektywnych odczuć, przeżyć oraz doznań badanych warunkujących ich aktywność w określonym wycinku rzeczywistości społecznej i/lub indywidualnej. Realizowane analizy powinny uwzględniać korelacje środowiskowe, otoczenie, w którym żyją badani, są to bowiem determinanty rzutujące na subiektywne interpretacje i znaczenia nadawane określonym zjawiskom. Ponadto w badaniach realizowanych metodą biograficzną wykorzystuje się różne źródła informacji, gdyż wszystkie pozwalają na efektywniejsze poznanie badanych osób. Dają możliwość ujęcia działań ludzi zarówno w aspektach historycznych, odniesionych do minionych doświadczeń badanych, jak i aktualnych - zachodzących „tu i teraz”. Metoda biograficzna w omawianych badaniach była szczególnie przydatna przy konstruowaniu sylwetek osób głuchoniewidomych oraz specjalistów z nimi pracujących.

Badania były realizowane osobiście przez ich pomysłodawczynię z osobami żyjącymi. Natomiast w odniesieniu do osób nie-żyjących zastosowano jakościową analizę tekstu (dokumentacja archiwalna, doniesienia prasowe, dorobek naukowy - publikacje) oraz wspomnień ludzi znających te osoby w przeszłości i mających z nimi bezpośredni kontakt (ojciec, rodzeństwo, mąż, uczniowie,

2 T. Bauman, O możliwości zastosowania metod jakościowych $w$ badaniach pedagogicznych, w: T. Pilch (red.), Zasady badań pedagogicznych, Wydawnictwo „Żak”, Warszawa 1995, s. $67-68$.

3 I.K. Helling (1990), Metoda badań biograficznych, w: G. Włodarek, M. Ziółkowski (red.), Metoda biograficzna w socjologii, PWN, Warszawa-Poznań, s. 13.

${ }^{4}$ B. Gołębiowski (1995), Metoda biograficzna w pedeutologii, w: W. Dróżka, B. Gołębiowski (red.), Współczesne zagadnienia zawodu nauczyciela, Wydawnictwo Pedagogiczne ZNP, Kielce, s. 31. 
wychowankowie, magistranci, doktoranci, współpracownicy). Także fragmentów filmów, gdzie były eksponowane ich postacis.

Co do drugiej metody, jakościowej analizy tekstu, zdecydowano się na następującą definicję samego terminu „tekst”: „,jest systemem znaków, który badacz próbuje uporządkować pod kątem zawartych w nim myśli, zrekonstruować przekonania ich twórców, wydobyć ukryte w nim założenia, zinterpretować kluczowe dla tekstu kategorie ${ }^{6} . "$

Ponieważ metoda biograficzna i metoda jakościowej analizy tekstu lokują się $\mathrm{w}$ strategiach badań jakościowych zrezygnowano z definiowania hipotez badawczych. Badania takie ,zakładają swoistą bezzałożeniowość na temat natury badanego zjawiska, wynikającą nie z braku jakichkolwiek założeń badacza, lecz z programowo przez niego przyjętej postawy „naiwnej poznawczo”. Istnienie hipotezy określa bowiem kierunek naszych poszukiwań, a tym samym redukuje je do uświadomionych przez badacza wątków, może przy tym pominąc całe spektrum zagadnień, z których badacz nie zdawał sobie sprawy." Ponadto uwzględnione metody postulują podmiotowe podejście do badanych. Przedmiotem jest bowiem poznawana kwestia. Język używany w badaniu jest: „językiem badanego lub wypadkową języków obydwu stron interakcji ${ }^{8}$."

W czasie realizacji badań wykorzystywano werbalne (mowa artykułowana) oraz niewerbalne metody komunikacji (pisanie liter drukowanych na dłoni, daktylografia do ręki, metoda TADOMA). Wskazane postępowanie zależało od metody porozumiewania się, którą posługiwali się badani. Wykorzystano również pomoc przewodników-tłumaczy, szczególnie w relacjach z badanymi głuchoniewidomymi z terenu Rosji. Ponadto wszystkie materiały badawcze pozyskane w trakcie przeprowadzania badań na terenie Rosji (wywiady, literatura naukowa, popularnonaukowa, doniesienia prasowe i inne) zostały zinterpretowane i przetłumaczone na język polski przez realizatorkę badań. $\mathrm{Na}$ zamieszczenie biogramów osób żyjących uzyskano ich zgodę oraz akceptację umieszczonych w nim treści.

Badania trwały dwa lata i przebiegały w czterech zasadniczych etapach: 1) przygotowawczy - koncentrował się na szczegółowym opracowaniu i przygotowaniu narzędzi badawczych w postaci kwestionariusza wywiadu narracyjnego z osobą głuchoniewidomą oraz specjalistami pracującymi z takimi osobami.

\footnotetext{
5 K. Rubacha (2008), dz. cyt., s. 157.

6 K. Podemski (1991), cyt. za: T. Bauman, dz. cyt., s. 69-70.

7 Tamże, s. 57.

8 Tamże, s. 61.
} 
Ponadto schematu opisu sylwetek badanych osób niepełnosprawnych i specjalistów pracujących na ich rzecz; 2) obejmowal kwestie poznania realnych rozwiązań w dziedzinie edukacji i rehabilitacji osób głuchoniewidomych w Rosji (w kontekście historycznym i współczesnym/aktualistycznym) oraz indywidualnych przypadków osób głuchoniewidomych (rys biograficzny). Chodziło o osoby, które zdołały uzyskać imponujący, jak na posiadaną niepełnosprawność, poziom rozwoju i samorealizacji w dorosłości, a także wybranych specjalistów, którzy wspierali/ją głuchoniewidomych w ich zmaganiach się z konsekwencjami ograniczeń zmysłowych (rys biograficzny specjalistów); 3) dotyczył eksploracji zagadnień edukacji i rehabilitacji osób głuchoniewidomych $w$ Polsce $w$ przeszłości oraz stanu obecnego, jak również indywidualnych przypadków głuchoniewidomych i ludzi działających na ich rzecz (rys biograficzny wybranych sylwetek osób głuchoniewidomych i kadry zajmującej się tymi osobami); 4) uogólnienie pozyskanych informacji i danych, porównanie zgromadzonych informacji i danych na temat organizacji systemu ksztalcenia gluchoniewidomych w Polsce i Rosji. Chodziło także o wnioskowanie na rzecz praktyki pedagogicznej w celu modyfikacji istniejących rozwiązań w dziedzinie edukacji i rehabilitacji głuchoniewidomych w Polsce.

Badania lokowały się w koncepcji pedagogiki personalistycznej oraz emancypacyjnej. Pedagogika personalistyczna podkreśla wartość i godność osoby ludzkiej oraz stara się w proponowanych programach wspierających rozwój człowieka podporządkować wartości ekonomiczne i techniczne - wartościom osobowo-duchowym ${ }^{9}$. „W naturze człowieka wyodrębnia dwa poziomy bytowe: życie biologiczno-wegetatywne i życie psychiczno-duchowe" ${ }^{10}$. Celem wysiłków wychowawczych jest uzdalnianie wychowanka (podmiotu) do pójścia w kierunku personalizacji. Inaczej - uzdalnianie wychowanka (podmiotu) do podjęcia kierownictwa nad własnym procesem rozwoju ${ }^{11}$. Wychowanek bowiem jest pierwszym i podstawowym czynnikiem wychowania, a wychowawca jest jedynie kooperatorem, współpracownikiem w tym dziele [...]; jako osoba wychowanek nie jest rzeczą ani rodziny, ani państwa [...]. Koncepcja stwierdza istotną rangę i rolę szkoły, ukazując jej zadania obok innych instytucji wychowawczych; podkreśla związek między nauczaniem a wychowaniem, poddaje

${ }^{9}$ M. Nowak (2003), Pedagogika personalistyczna, w: Z. Kwieciński, B. Śliwerski (red.), Pedagogika. Podręcznik akademicki, t. 1, Wydawnictwo „Impuls”, Kraków.

10 Tamże, s. 239.

11 Tamże. 
krytyce i odrzuca koncepcje „szkoły neutralnej”; treścią nauczania szkolnego jest ,integralny humanizm”, a więc nie tylko literacki czy artystyczny, lecz też naukowy i techniczny; potwierdza i broni wychowawczej funkcji rodziny [...] podkreśla [...] respekt dla „tajemnicy dziecka”, które staje się osobą, przy oddziaływaniu wielorakich bodźców pochodzących od różnych instytucji wychowawczych."12

W pedagogice emancypacyjnej ,istotą wychowania, nauczania i teorii pedagogicznej jest wyzwalanie, które obejmuje wyzwolenie osoby, jej umysłowości, jak i związanej z nią sfery zachowań społecznych. Podstawową kwestią jest zmiana rozumienia form życia i form jego wyobrażenia, co jest związane $z$ odchodzeniem od świadomości, że są one naturalne, i dochodzeniem do świadomości, że są one uwarunkowane i zapośredniczone społecznie. Daje to możliwość kontroli nad nimi. Samo uświadomienie sobie przez jednostkę narzuconych społecznie i rządzących nią, alienujących wyobrażeń, sposobów myślenia i postępowania daje jej szansę oddziaływania na nie w sposób krytyczny. Celem pedagogiki emancypacyjnej w wymiarze jednostkowym nie jest osiagnięcie dojrzałości rozumianej jako opanowanie zaplanowanego repertuaru „właściwej wiedzy” i „dobrego zachowania”. Jej założeniem jest przekonanie, że uświadomienie sobie ograniczeń pozwoli jednostce na lepsze ukierunkowanie i wykorzystanie własnego potencjału ${ }^{13}$." Podstawą pedagogicznych działań emancypacyjnych jest tzw. racjonalność emancypacyjna. „Racjonalność emancypacyjna zmierza - zdaniem Z. Kwiecińskiego - do poszukiwania możliwości wyzwalania się z wcześniej stworzonego i zaakceptowanego świata. 'Wartością jest więc tu otwieranie się na nowe, a przy tym wypowiadanie we własnym imieniu wartości, na nowe znaczenia i nowy sposób doświadczania świata ${ }^{14}$."

„Emancypacja ma jedną stałą cechę, a jest nią zmiana. Emancypowanie się nie jest dochodzeniem do ustalonego wcześniej celu, zgodnie z czyimś nakazem czy według jakichś określonych reguł. To proces ciagły i twórczy. [...] Jego celem jest odkrywanie i rozumienie coraz to nowych horyzontów."15 „W perspektywie emancypacyjnej nauka, jako sposób uprawiania wiedzy, i jej dyskursy stają się elementem życia codziennego, gdyż wyrażają realne »interesy« i potrzeby poszczególnych ludzi i społeczności. Dyskurs nauki wyrasta

12 Tamże, s. 247.

${ }_{13}$ H. Zielińska-Kostyło (2003), Pedagogika emancypacyjna, w: Z. Kwieciński, B. Śliwerski (red.), Pedagogika. Podręcznik akademicki, t. 1, Wydawnictwo „Impuls”, Kraków, s. 394.

${ }^{14}$ Z. Kwieciński (2000), Tropy - Ślady - Próby. Studia i szkice z pedagogiki pogranicza, Wydawnictwo Edytor, Poznań-Olsztyn, s. 16-17.

${ }^{15}$ H. Zielińska-Kostyło, dz. cyt., s. 412. 
z artykułowanych przez ludzi oczekiwań i ich gotowości do dialogu, obejmuje oryginalne, jednostkowe pomysły, jak i powszechne zdroworozsądkowe rozumienie problemów, które ujmuje w perspektywie analiz ${ }^{16}$."

\section{Możliwości i ograniczenia organizacji oraz realizacji badań naukowych osób dorosłych z niepełnosprawnością sprzężoną (głuchoniewidomych) za granicą}

Analizując zagadnienia organizacji badań naukowych osób głuchoniewidomych za granicą (na przykładzie Rosji) w kontekście ewentualnych trudności, ograniczeń, jak również możliwości, można i należy wskazać na co najmniej kilka istotnych komponentów. Jednym z nich jest niewątpliwie opracowanie oraz zaplanowanie strategii realizacji wywiadów narracyjnych z dorosłymi osobami głuchoniewidomymi w aspekcie czasu ich realizacji i długości trwania, uwzględnienia kontekstów dezorganizujących ich przebieg oraz hipotetycznych ograniczeń o charakterze stricte organizacyjnym, sytuacyjnym i mentalnym.

W obszarze determinantów sytuacyjnych znajdują się między innymi: zagraniczne miejsce realizacji badań (inne państwo), inny język porozumiewania się, czasowe, wynikające z okresu pobytu za granicą ograniczenie realizacji badań i związane z ograniczeniem czasowym - ograniczenie finansowe, wiążące się z kosztami pobytu badacza za granicą i kosztami, które są wydatkowane na wykonanie badań.

W obszarze ograniczeń sytuacyjnych można podać: potrzebę określenia miejsca/przestrzeni przeprowadzania wywiadów (np. w domu osoby badanej, $\mathrm{w}$ pomieszczeniach będących $\mathrm{w}$ posiadaniu instytucji pozarządowych, edukacyjnych, społecznych, czy kulturalnych) i uwzględnienia wszystkich możliwych czynników mogących zaburzyć ich przebieg oraz wpłynąć na uzyskane informacje, konieczność wykorzystania niewerbalnych metod komunikacji oraz thumacza, a nawet tzw. thumacza-przewodnika.

Co do kwestii niewerbalnych metod komunikacji należy podkreślić, że obecne ograniczenia może wywoływać nie tylko odmienne językowo środowisko, ale przede wszystkim brak możliwości werbalnego kontaktu $\mathrm{z}$ badanym. Stosowanie niewerbalnej metody komunikacji z jednej strony jakoby automatycznie wymusza potrzebę skorzystania z usług thumacza, ewentualnie thumacza-przewodnika, z drugiej może powodować, że uzyskane informacje będą naznaczone, zdeterminowane subiektywnym widzeniem problemów badanego

16 Tamże, s. 413. 
i nie będą osobistą oraz rzeczywistą ich percepcją przez samą badaną osobę. Komunikacja bowiem odbywa się poprzez pośrednika, a niewerbalna metoda komunikacji może, za przyczyną reinterpretacji i dostosowywania zadawanych pytań do stosowanej metody porozumiewania się, zaburzać, a nawet deformować przekaz na continuum badacz-tłumacz-badany-badany-tłumacz-badacz. Uzyskiwane odpowiedzi mogą też być opinią tłumacza lub częściowo opinią na analizowany temat badanego i thumacza, albo częściową opinią tłumacza i badanego. Na to wszystko może nakładać się językowy kontekst przekazu, językowy niuans obecny w każdym środowisku językowym i częstokroć trudny do zidentyfikowania dla osoby spoza innego kręgu językowego, jak również kulturowego. Ponadto, mimo obecności ogólnoświatowych wariantów niektórych metod komunikacji niewerbalnej (np. alfabetu palcowego), na ogół osoby niepełnosprawne stosują metody zaadaptowane do specyfiki ich języka ojczystego oraz nie znają alternatyw międzynarodowych. Na wskazane uwarunkowania nakłada się więc nie tylko metoda komunikacji i sposób jej zastosowania, specyfika miejsca/przestrzeni realizacji badań, specyfika odmienności narodowej, ale również podświadome zachowanie badacza, nacelowane na uwzględnienie sytuacji, w której się znajduje, wyrażone w działaniach na rzecz uzyskiwania/uzyskania akceptacji siebie w oczach badanego i pomocnika w realizacji badań, tj. tłumacza lub thumacza-przewodnika, jako osoby otwartej, komunikatywnej, kompetentnej, ale też będącej petentem wobec podmiotu badań. To z kolei może skutkować subiektywną interpretacją uzyskiwanych danych, znaczącym obciążeniem psycho-emocjonalnym, a nawet fizycznym. Również z racji badań terenowych z zastosowaniem techniki wywiadu, pozwalającej na stosunkowo dużą swobodę $\mathrm{w}$ jej realizacji istnieje spore niebezpieczeństwo odejścia od zasadniczej tematyki badań na zagadnienia poboczne, mniej ważne i nieznajdujące się $\mathrm{w}$ bezpośrednim związku $\mathrm{z}$ realizowaną strategią badawczą.

W kategorii hipotetycznych ograniczeń mentalnych należy uwzględnić obecne różnice historyczno-kulturowe i socjo-kulturowe, w tym też możliwie odmienne poglądy na badane zagadnienia, inny i czasami niekorespondujący z percepcją badacza sposób myślenia o przeszłym i aktualnym (wynikający np. z różnej struktury organizacji systemu edukacji, różnych poglądów i treści nabytych w czasie kształcenia i wychowania, a zatem zinterioryzowanych przez badaną osobę, różnej sytuacji społeczno-politycznej kraju czy lokalnego środowiska codziennego życia badanego) - co nie oznacza gorszy i zasługujący na deprecjonowanie, odmienne preferencje religijne czy światopoglądowe (np. religia prawosławna). 
Jeśli zaś idzie o możliwości, które tworzy realizacja badań osób dorosłych z niepełnosprawnością sprzężona, na przykładzie osób głuchoniewidomych w innym państwie, to można je ująć zarówno w perspektywie ogólnej, jak i skonkretyzowanej celem badań. Perspektywa ogólna dotyczy przede wszystkim faktu umiędzynarodowienia badań, szans na uzyskanie wyników wychodzących poza obszar badań zlokalizowanych na konkretnym terenie, porównania istniejących tendencji co do analizowanego zagadnienia i przełożenia badań na korelaty mentalne, socjo- $\mathrm{i}$ historyczno-kulturowe oraz wprowadzenia elementu rzeczywistego novum, bez zarzutu powielania badanej problematyki. Natomiast perspektywa skonkretyzowana celem badań dotyczy opracowania zweryfikowanych innymi doświadczeniami propozycji, możliwie że szerszych zakresowo i treściowo, adresowanych do praktyki pedagogicznej, a ukierunkowanych na poważne i zasadne oraz niejednokrotnie reformujące od podstaw istniejące rozwiązania systemowe, organizacyjne czy nawet realizacyjne.

\section{Podsumowanie}

Badania naukowe osób z niepełnosprawnością sprzężoną tworzą dla badacza ogromne możliwości zarówno w wymiarze stricte naukowym, czy nowatorstwa badanej problematyki, jak i sprawdzenia siebie samego jako osoby kompetentnej, przygotowanej do bycia badaczem prawdziwie obiektywnym, potrafiącym podejmować i realizować wyzwania nie tylko ukierunkowane na zakładany cel, ale także o charakterze ponadlokalnym. Wyzwalają też konieczność zmierzenia się z określonymi trudnościami i ograniczeniami, poszukiwania alternatyw oraz sposobów ich pokonywania. Wszystko to wpływa na budowanie własnego doświadczenia badawczego oraz doskonalenie naukowego warsztatu, wyczulonego nie tylko na obiektywizm, ale też potrzeby osób stanowiących podmiot podjętych badań.

\section{Bibliografia}

Bauman T. (1995), O możliwości zastosowania metod jakościowych w badaniach pedagogicznych, w: T. Pilch (red), Zasady badań pedagogicznych, Wydawnictwo „Żak”, Warszawa.

Gołębiowski B. (1995), Metoda biograficzna w pedeutologii, w: W. Dróżka, B. Gołębiowski (red.), Wspótczesne zagadnienia zawodu nauczyciela, Wydawnictwo Pedagogiczne ZNP, Kielce. 
Helling I.K. (199), Metoda badań biograficznych, w: G. Włodarek, M. Ziółkowski (red.), Metoda biograficzna $w$ socjologii, PWN, Warszawa-Poznań.

Kwieciński Z. (2000), Tropy - Ślady - Próby. Studia i szkice z pedagogiki pogranicza, Wydawnictwo Edytor, Poznań-Olsztyn.

Nowak M. (2003), Pedagogika personalistyczna, w: Z. Kwieciński, B. Śliwerski (red.), Pedagogika. Podręcznik akademicki, t. 1, Wydawnictwo „Impuls”, Kraków.

Rubacha K. (2008), Metodologia badań nad edukacja, Wydawnictwo Akademickie i Profesjonalne, Warszawa.

Zaorska M. (2010), Edukacja i rehabilitacja osób głuchoniewidomych w Polsce i Rosji (rozwój i stan obecny), Wydawnictwo UMK, Toruń.

Zielińska-Kostyło H. (2003), Pedagogika emancypacyjna, w: Z. Kwieciński, B. Śliwerski (red.), Pedagogika. Podręcznik akademicki, t. 1, Wydawnictwo „Impuls”, Kraków.

\section{Organization and realization of scientific research on adults with multiple disabilities (on the example of deaf-blind people) abroad - possibilities and limitations}

\section{Summary}

Scientific research on adults with multiple disabilities (for example: deaf-blind) are highly complicated when it comes to their completion, and organizational aspects. Additionally, in many cases, they require the use of non-verbal methods of communication, adequate to the methods, that research study subjects use. The realization of scientific research on adults, with multiple disability, abroad is determined not only by mental, or financial aspects, but also the need to implement an additional participant - the translator, or so called translatorguide. In the text of the article possible limitations regarding organization and realization of the scientific research on adult deaf-blind people abroad are highlighted, as well as the unquestionable possibilities in the stricte scientific context, and the merits concerning the researcher.

Keywords: scientific research, organizing of scientific research, deaf-blind people, education, rehabilitation, multiple disabilities. 